\title{
Tóth Zoltán
}

\section{Németország brit szemmel}

\author{
Recenzió Paul Lever: Berlin rules - Europe \\ and the German way ${ }^{1}$ címü könyvéről
}

\section{Germany from a British Perspective}

Paul Lever, mint életrajzából kiderül, egész életét különböző beosztásokban, hol NagyBritanniában, hol pedig külszolgálatban, diplomataként töltötte. 1997-2003 között Berlinbe akkreditált brit nagykövetként dolgozott, majd egy brit védelmi és biztonsági ügyekkel foglalkozó think tank vezetője ${ }^{2}$ volt. Ez utóbbi pozícióban elsősorban gazdasági problémákkal, elsősorban az Európai Unió gazdaságpolitikai kérdéseivel foglalkozott.

Könyve (Berlin rules - Europe and the German way) 2017-ben jelent meg, és már csak ennélfogva is érdeklődésre tarthat számot, hiszen egy friss, számos aktualitást tartalmazó pillanatfelvétel Németországról. Ugyanakkor pedig a jelen politikai és gazdasági történéseinek mélyebb mozgatórúgóit egészen a második világháború lezárását követő időkig visszavezető analízis.

A múvet kézbe véve hamar világossá válhat az olvasó számára, hogy mindaz, amit a szerző tapasztalt diplomataként, külügyi szakemberként Németországgal összefüggésben elmond, azt részben a külső megfigyelő józanságával ${ }^{3}$ teszi, másrészt mindvégig annak tudatában, hogy Nagy-Britannia egyik legfontosabb partnere, az Európai Unió meghatározó hatalma.

A könyv mégis olvasmányos, helyenként könnyed, szerepet kap benne néhány személyes emlék, találkozó, és mindenkor hangsúlyos a történelmi háttér, amely a kicsit tájékozottabb olvasó számára talán olykor túl soknak is tűnik. A részletes magyarázatok a német politikai rendszerről, annak résztvevőiről, törekvéseikről a napi sajtóból ismerősek lehetnek azok számára, akik igyekeznek követni Európa nyugati felének politikai történéseit.

A szerző nem bizonyít, nem tesz lábjegyzeteket, alig hivatkozik néhány szakmunkára, inkább kijelent és megállapít, de mivel több évtizeden át foglalkozott az Európai Unióval, az európai hatalmi-gazdasági viszonyok elemzésével, így érdekessé válik

Tóth Zoltán a Nemzeti Közszolgálati Egyetem Közigazgatás-tudományi Doktori Iskola PhD-hallgatója. E-mail: volsinii@gmail.com Lever, Paul (2017): Berlin rules - Europe and the German way. London - New York,, I.B. Tauris \& Co. Royal United Services Institute (RUSI). 
számunkra is érvelése, különösen pedig az a speciálisan brit nézőpont, amely a magyar olvasó számára feltehetően nem annyira közismert.

Talán ez utóbbi a legfőbb értéke a könyvnek, a brit és a német viszonyok, közélet, hatalmi szerkezet, gazdasági élet szembeállítása, egymásra vetítve, mintegy egymás - torz - tükrében (is) szemlélve a másik országot, annak legjellemzőbb vonásait. Jól kirajzolódik nem csupán Németország, de Nagy-Britannia egymástól oly markánsan különböző politikai és üzleti felfogásának egészen eltérő mivolta, a kontinentális német és az angolszász tradíció különbsége.

Lever már könyvének elején leszögezi, véleménye szerint az Európai Unió gyakorlatilag német mintára, a német gazdasági és politikai érdekek képviseletére épül. Ezt a későbbiekben talán csak annyiban finomítja, hogy vannak olyan politikai-gazdasági témák, területek, amelyek mintegy kiesnek Németország érdeklődésének köréből. A német politikai-gazdasági elit tagjai történelmi okokból - elsősorban a 20. század első felének, a nácizmusnak, a második világháborúnak következményeképp - nem vagy csak nagyon óvatosan nyúlhatnak bizonyos témákhoz, foglalkozhatnak egyes problémákkal, foglalhatnak állást, akár még Németország számára a külső szemlélőként fontosnak látszó érdekek képviseletében is.

Fenti kijelentését alátámasztva megállapítja, hogy ma már nem lehet az Európai Bizottság élére olyan elnököt választani, aki ne a német érdekeket képviselné. JeanClaude Juncker csak német támogatással lehetett a Bizottság elnöke, a tagállamok közül csak Nagy-Britannia és Magyarország próbált ennek ellenállni. Majd Juncker vezetése alatt az Európai Unió vezető testületeibe, az egyes szakmai területeket irányító főigazgatóságok vezetőjeként és vezetők munkatársaiként nagyszámú német tisztviselő került be. (Németország természetesen lakosságszáma alapján is a legnagyobb arányban képviselteti magát az uniós döntéshozó testületekben, a szakpolitikai végrehajtó szervezetekben.)

Lever utal arra is, hogy a 2008-2009-ben kirobbanó pénzügyi-gazdasági válság következményeként meghozott intézkedések zöme is német érdekeket szolgált, mind Merkel kancellár, mind Wolfgang Schäuble pénzügyminiszter döntő szerepet játszott az uniós válságkezelés minden egyes döntésének meghozatalában. A felhalmozott adósságok visszafizetésének feltétlen megkövetelése, az adósságelengedés minden formájának kizárása a német gazdaság érdekeit szolgálta Lever szerint.

Viszont már itt, könyve elején megfogalmazza azt a későbbiekben többször megismételt álláspontját, hogy a német politika legfőbb hibája, hogy nincs jövőképe. Nincs hosszú távú elképzelése az Európai Unióról, nem tud olyan közös célt megjelölni, víziót felmutatni, amely a tagállamok többségét, vezetőiket, illetve lakosságuk jelentős részét képes lenne az Unió eszméjének megnyerni - a német Európa-politika: „power without purpose".

A német gazdaság sikerességének hátterét, a gazdaságirányítás intézményeit, szervezeti struktúráit és a vállalati kultúra speciálisan német elemeit is hosszan elemzi a szerző. Véleménye szerint a szakképzés-oktatás a gazdaság igényeinek is messzemenőkig megfelelő, emellett a kutatás szabadságát biztosító egyetemi-kutatóintézeti hálózat működését, a belföldi közép- és kisvállalatok és a nagy, multinacionális cégek múködését meghatározó tényezőket egyaránt igyekszik összefoglalni. A szakszervezetek, a vállalati 
tanács (Betriebsrat), a vállalatirányítás (Vorstand) és felügyelőbizottság (Aufsichtsrat) szerepét emeli ki, amelyek együttesen teszik lehetővé a munkavállalói és tulajdonosi érdekek érvényesülését (Mitbestimmung), olyan - Lever szerint is - speciálisan német gazdasági rendszert, amely az egyik legsikeresebb a világon, és talán kimondható, hogy az első helyen áll az Európai Unióban.

Megjegyzi ugyanakkor, hogy a német gazdaság, vállalatirányítás rendszerébe Németország nem tûri el az Európai Unió részéről a beleszólást, és igyekszik megakadályozni minden olyan rendelkezés meghozatalát, amely rontaná a német cégek versenyképességét.

Ami pedig a brit - angolszász - elemző számára meglehetősen idegen, az az állami beavatkozás viszonylag magas szintje. A tartományi (Land) vagy szövetségi állam kezében lévő aranyrészvény, helyi - az adott térséghez, tartományhoz kötődő - pénzintézet biztosította támogatás, amellyel megakadályozható a részvényesek profitmaximalizáló érdekeinek korlátlan érvényesülése vagy az ellenséges felvásárlás.

A német gazdasági élet további meghatározó tényezője a hitelektől, kölcsönfelvételtől való tartózkodás, az eladósodottsággal szembeni félelem, illetve a takarékosságra való törekvés, a magas megtakarítási hajlandóság. Ez ismét csak jelentős eltérést mutat a brit és főleg az amerikai szemlélettől.

Természetesen ennek a gazdasági tradíciónak is megvannak a történelmi okai. A háború utáni újjáépítés, a munka tisztelete, mindaz, amit más oldalról már Max Weber a protestáns etika hatásának tulajdonított, jóllehet erről Lever nem tesz említést.

Viszont a szerző szerint a németekben még az újraegyesítés nehéz, fájdalmakkal teli, de alapvetően sikeres folyamata is csak azt a meggyőződést erősítette meg, hogy ha egy egész államot - az egykori NDK-t - fel is kellett számolni, mégis az ennek érdekében elvégzett munka végül sikerre vezetett. Ennek analógiáját látja abban a német válságkezelési stratégiában, amely a 2008-2009-es válság során súlyos helyzetbe került uniós tagállamokat csak a lehető legminimálisabb szinten kívánta segíteni, mondván, elsősorban saját erejükre kell(ene) támaszkodniuk problémáik megoldásában.

A könyv több fejezetében is vissza-visszatér az euró mint fizetőeszköz, mint Európa - nem csupán gazdasági szempontú - egyesítésének szimbóluma, eredménye és problémája.

Természetesen az euróval kapcsolatban megfogalmazódó összes érv és ellenérv valamely formában felbukkan itt. Az euró bevezetése, amelynek esetében jóval szúkebb körre - Németország, Franciaország, Benelux államok, Ausztria, Finnország - gondoltak tervezői. A három százalékos költségvetési hiánycél betartásának nehézségei. Az euróövezet központi pénzügyi irányításának és közös költségvetésének, valamint az adóharmonizáció, szociális juttatások/kiadások összehangolásának hiánya, de legalábbis nagyon lassú előrehaladást mutató tárgyalásai, gyakorlati lépései.

Lever vélhetően a brit politikai osztály és szakértők jelentős részének véleményét osztja meg olvasóival akkor, amikor az Európai Unió felépítését, intézményrendszerét párhuzamba állítja Németországéval, azt állítva, hogy gyakorlatilag ez is a német állam majdnem tökéletes tükörképe.

Jellemző és nagyon szemléletes felfogására nézve, ahogy az 1871-es katonai győzelem, az egységes német állam és császárság kikiáltásának emlékére emelt Brandenburgi Kapu quadrigájának lovai szimbolizálják számára a szövetségi kormány, parlament 
(Bundestag), a tartományokképviselőialkotta felsőház (Bundesrat) ésAlkotmánybíróság, illetve az Európai Unió irányító szervezetei - az Európai Bizottság, Parlament, Tanács, Bíróság párhuzamos struktúráját.

Az uniós versenypolitika és szociális partnerség pedig a német szövetségi versenyhivatal (Bundeskartellamt) és munkaadói, szakszervezeti szövetségek alkotta szervezetekre emlékezteti a briteket.

Lever elismeri, hogy az unió szervezetére és múködésére nagy hatást gyakorolt a francia bürokrácia, és a francia politika nagy hatással van elsősorban az agrárügyek intézésére, de az a meggyőződése, hogy az utolsó közel harminc évben - legalábbis az újraegyesítés óta - a német befolyás a döntő.

Ami különösen érdekes és valóban megfontolást érdemel, az az a felfogás, ahogy Nagy-Britannia szempontjából úgy ábrázolja Németországot, mint amely elvesztette, megtagadta történelmét.

A land without a past - Múlt nélküli ország - hangzik a német történelemmel foglalkozó fejezet címe. Az itt leírtak elsőként meghökkentőnek tűnnek, de el lehet fogadni a szerző érvelését. Németország nem támaszkodhat sem a császárság és különösen nem a náci korszak történelmi emlékeire, a weimari köztársaság pedig politikai szempontból ismét csak inkább rossz emlék, amely a demokratikus berendezkedés csődjét hozta magával.

Az 1960-as évektől folyó erőteljes nevelőmunka, tudatformálás, a német társadalom demokratikus attitűdjének kialakítása, de a második világháborút követő kétállami lét és a német politikai rendszer nagyon gondos átalakítása is - amelynek elsődleges célja a demokratikus államforma fenntartása és megőrzése - valóban a múlt eltörlése, felszámolása irányába hatottak.

Lever megjegyzése ismét nagyon fontos tényre világít rá, ami nem biztos, hogy a szélesebb olvasóközönség előtt ismert: Ma Németország nagyon egységes identitását tekintve, a tartományok lakói már nem a régmúlt német államainak megfelelően szászként, svábként, pfalziként, még talán nem is elsősorban bajorként stb. jellemzik saját magukat. De még a minden birodalmi lakost németként nyilvántartó útlevél bevezetése is 1934-ben, egy évvel Hitler hatalomra jutását követően történt meg.

Egy, a múltjától megszabadulni kénytelen - megszabadulni akaró - ország számára pedig az Európai Unió kiváló megoldás. Lever szerint a németek mint európai polgárok tudnak leginkább büszkék lenni önmagukra. A vérségi leszármazás és jogi, állami szinten a kettős állampolgárság bevezetésétől való hosszú ideig tartó vonakodás ugyan jelzi ennek az „európaizálódásnak” a határait, de az előbbi gondolatmenet az olvasó számára hitelesnek tűnik.

Lever - még ha idegenkedik is tőle - elismeri a saját maga által felvázolt német modell sikerességét. Németország több esetben képes volt arra, hogy akár az uniós ügyekben legszorosabb szövetségese, Franciaország, akár pedig kisebb partnerei érdekeit is figyelembe vegye (Görögország és Ciprus felvétele, sőt a görög eurócsatlakozás jóváhagyása mint potenciális politikai/gazdasági válsággócok Európai Unióba, euróövezeten belülre kerülésének problémája). Másrészt újra meg újra hangsúlyozza azt a meggyőződését, hogy az exportorientált német gazdaság és euróövezet elsősorban német érdekeket 
szolgál, így a kompromisszumok inkább egy racionális megfontolás termékének tekinthetők, mintsem valamiféle erkölcsi, érzelmi okokra vezethetőek vissza.

A francia kapcsolat elemzése, a „különleges viszony”, a „tandem” bemutatásának végén pedig újra eljutunk oda, hogy Lever szerint a fokozatosan gyengülő francia gazdaság nem tette lehetővé a francia kormányoknak, hogy akár a 2008-2009-es pénzügyi-gazdasági válság kezelésének módjairól, akár pedig egyéb uniós ügyekben komoly ellenállást fejtsenek ki a német törekvésekkel szemben. Franciaország természetesen külpolitikai téren nagyon aktív tud lenni (például Sarkozy líbiai politikája), a Biztonsági Tanács állandó tagjaként és atomhatalomként pedig mindenképp figyelembe kell venni érdekeit, véleményét, de ez nem fogja gátolni Németország uniós törekvéseit.

Ami talán ismét kisebb meglepetést kelthet a könyv olvasói számára, az Lengyelország említése. Németország számára Lever szerint Franciaország mellett a legfontosabb partner Lengyelország. Részben mint szomszédos ország, részben mint munkaerőforrás (1,5 millió lengyel dolgozik Németországban). Merkel mindig igyekezett a lengyel érdekekre odafigyelni, fontosnak tartja, hogy a 2004-ben csatlakozott államok közül a legnagyobbal jó együttmúködést alakítson ki (még a jelenleg zajló - jogállamisággal összefüggő - uniós kritikák és történelmi sérelmekből fakadó bizalmatlanság ellenére is).

A könyv érthető módon jelentős figyelmet szentel a német-brit viszonynak, ami, mint ahogy a korábbiakban is említettük, külön értéket és speciális megközelítést ad ennek a szélesebb olvasóközönségnek írt műnek.

Lényegében Lever arra a következtetésre jut, hogy a két ország kapcsolata soha nem volt igazán szoros. Talán a Schröder-kormány idején irányult igazán figyelem Nagy-Britanniára német részről, de még ezt is inkább felületesnek ítéli meg a szerző. Tulajdonképp a sérelmek dominálnak leírásában. Az európai monetáris rendszer bevezetésekor a valutaárfolyamok egymáshoz való rögzítését szabályozó mechanizmus kialakítása ügyében folytatott német nyomásgyakorlás vagy a brit múvészeti piac érdekeinek figyelmen kívül hatása sokkal jelentősebb hangsúlyt kapnak, mint az együttmúködési hajlandóság a két ország között.

A német-brit viszony, közös fellépés, érdekek felsorolása elég szűk körre korlátozódik a szerző szerint. Talán bizonyos katonai-védelmi együttműködés, illetve a négyhatalmi egyezmény keretében Nagy-Britannia fegyveres erőinek németországi jelenléte idején megvalósuló kooperáció pozitív emlékei kapnak itt helyet. A továbbiakban viszont inkább csak az eltérő pénzügyi-gazdasági felfogásból eredő ellentétek a meghatározóak véleménye szerint. Lever azt állítja, a németek nem vették komolyan a brit kifogásokat az unió gazdasági szabályrendszerének kialakítása folyamán. Az euróövezet és az eurót bevezetni nem kívánó tagállamok számára kialakítandó kötelezettségek és jogok világos elhatárolása nem történt meg. A britek nehezményezték az integrációval kapcsolatos elképzelések - azok lehetséges mélységét, mértékét egyértelműen meghatározó megállapodások - hiányát. Határt kívántak szabni az integrációnak, semmiféle konföderáció felé elmozduló uniót nem támogattak, támogatnak.

Mindehhez társult Lever szerint, hogy a németek - Merkel kancellár személyesen is - teljesen érzéketlennek mutatkoztak a Kelet-Európából Nagy-Britanniába áramló, munkát kereső tömeg - bevándorlásproblémájával szemben. Ez csak felgyorsította a Brexit felé vezető politikai folyamatokat. Nem lett volna szabad - álláspontja szerint - a német félnek annyira mereven ragaszkodni az Európai Unión belül történő 
szabad mozgás elvéhez. (Lever csak röviden utal arra, Merkel félelme ezzel kapcsolatban az, hogy ha egy ilyen alapvető kérdésben enged, akkor a többi uniós alapjog is előbbutóbb megkérdőjeleződhet a későbbiekben.)

Összefoglalóan Lever sorait olvasva a német (Európai Unió) - brit viszonyról egyre inkább az a benyomás alakulhat ki bennünk, hogy lényegében nem volt olyan kérdés, amelyben Nagy-Britannia és az Európai Unió egyetérthetne, ugyanakkor pedig az Európai Unió minden döntése, intézkedése mögött Németország befolyását fedezhetjük fel. Így hiába hangzik el néhány békülékenynek szánt mondat és a két ország közötti kölcsönös megbecsülést emlegető udvarias kijelentés, tulajdonképp az az érzés alakulhat ki az olvasóban, hogy Nagy-Britannia kiválása szükségszerú, talán inkább az a csoda, hogy eddig része volt az uniónak.

A könyv utolsó három fejezetében ismét visszatérnek azok a témák, amelyeket már a korábbiakban megismerhettünk:

- A német politika nem tudja meghatározni, milyen célt adjon az uniós együttmúködésnek, és ez Lever szerint több tagállamnak, de különösen NagyBritanniának elfogadhatatlan.

- A német gazdaság és gazdaságpolitika ellenőrzése alá vonta, és ott is kívánja tartani a továbbiakban is az Uniót.

- A német gazdasági erők - és kormányzat - határozottan fellép saját érdekei mentén, ha olyan uniós szabályozás van születőben, amely számára nem megfelelő, vagy arra a következtetésre jut, hogy őt versenyhátrány érheti annak révén, hogy a többi tagállam is hozzá hasonlóan próbálja meg saját iparát, gazdaságát a közös szabályozás egyes hiányosságait kihasználva előnyhöz juttatni.

- $\quad$ szociális és környezetvédelmi szabályok német előírásokhoz igazítása;

- Merkel megpróbált lobbizni a 2013-as Volkswagen-botrányt, a károsanyagkibocsátás adatait érintő szoftverhamisítást követő büntetőintézkedések határidejének kitolásáért;

- a német áramszolgáltatók - RWE, EON - előnyhöz juttatása az uniós piacnyitás kierőltetése révén.

- Az Európai Unió kül- és védelmi politikájának gyengesége mögött azon túl, hogy ez alapvetően inkább a kormányközi együttmúködésre épül (eltekintve az Európai Külügyi Szolgálat felállításától és az EU Külpolitikai Főképviselője poszt létrehozásától), Németország külpolitikájának sajátosságai állnak.

Lever művét óvatos jövőbetekintéssel, az elkövetkezendő húsz évben várható fejlemények áttekintésével zárja.

Számba véve azokat a lehetőségeket, amelyek az Európai Unió esetleges további bővítését jelenthetik, rövid úton kizárja annak lehetőségét, hogy akár Törökország, akár a másik jelentősebb népességgel és gazdasági-politikai potenciállal rendelkező Ukrajna taggá válhatna. Törökország esetében valamiféle különleges státuszt még elképzelhetőnek tart, de Ukrajna - jelenleg káoszba hajló és Oroszországgal folyamatos háborús konfliktusban álló - helyzetét áttekintve ez utóbbi esetben még erre sem lát reális esélyt.

Németország szempontjából a status quo fenntartását jelöli meg mint az ország eminens érdekét. Jóllehet - és ebben egyet kell érteni vele - Nagy-Britannia kilépése az unióból mindenképp veszteséget jelent Németország számára is, mert a jelenlegi 
problematikus együttmúködés ellenére még jobban megnehezedhet a kétoldalú kapcsolatok fenntartása, fejlesztése a jövőben.

Paul Lever műve mindenképp érdekes és értékes olvasmány, naprakész, friss és számos olyan információt megoszt olvasóival, amelyet egy gyakorlati szakember tud csak igazán közvetíteni hitelesen. Kritikaként megemlíthető, hogy többször is előkerülnek ugyanazok a témák, elsősorban a német gazdasági fölény és annak egész Európai Unióra gyakorolt befolyása, éppúgy, mint a német politika koncepciótlanságának vádja. Egyrészt jobb lett volna, ha egy helyen, egy-egy fejezetben kaptak volna ezek a témák helyet. Másrészt a negatív hatásokról éppen csak érintőlegesen tud meg valamit az olvasó, aki így nem tudja igazán értékelni ezeket az állításokat, nem biztos, hogy átlátja, miért olyan károsak ezek a könyv szerzője szerint.

\section{Felhasznált irodalom}

Lever, Paul (2017): Berlin rules - Europe and the German way. London-New York, I.B. Tauris \& Co. DOI: https://doi.org/10.5040/9781350985490

\section{Internetes forrás}

BARBER, Tony (2017): The calm at the eye of Europe's storm. Financial Times. Elérhetö: www.ft.com/content/663a2c44-29af-11e7-9ec8-168383da43b7 (A letöltés dátuma: 2019. 11. 15.) 
